\title{
Sensitivity Analysis of Suspected External Driving Factors Contributing to Land Use Land Cover Dynamics in Jos Plateau State, Nigeria
}

\author{
Zitta N. ${ }^{1, *}$, Musa A. A. ${ }^{2}$ and Muhammed I. ${ }^{3}$ \\ ${ }^{1}$ Department of Surveying and Geoinformatics, Federal University of Technology, Minna, Nigeria \\ ${ }^{2,3}$ Department of Surveying and Geoinformatics, Modibbo Adama University, Yola, Nigeria \\ Corresponding Author: *bawazitta@gmail.com
}

https://doi.org/10.36263/nijest.2022.01.0297

\begin{abstract}
Land use land cover change (LULCC) processes are directly or indirectly product of underlying causative factors playing out on the landscape. This study examines the contributing factors responsible for LULCC in Jos Plateau state using two different methods. The Analytical hierarchical process (AHP) and Binary models were used to prepare sixteen (16) suspected external driving factors (EDFs). Euclidean distance analysis was carried out on the proximity EDFs as well as reclassification based on AHP scale $1-9$ and binary mode as 1 \& 0 . Saaty's pairwise comparison matrix was employed to generate the weights for all the EDFs with a consistency index (CI) of 0.17 was achieved. Suitability images were generated by multiplying each $E D F$ with the corresponding weight. The fuzzy set membership standardization was carried out on the AHP image through sigmoidal function type with monotonically increasing membership function.The multiple regression technique was used to measure the sensitivity of each driver against the change period (1986 - 2019). The result shows that five (5) EDFs where consistent in both approaches (AHP \& Binary). They are: distance to conflict areas, distance to major roads, LULC, distance to settlements and distance to river/ channels. It is therefore, appropriate to examine EDFs to know how each driver is contributing to the changing landscape in the study area. The findings has revealed the main factors driving LULC changes in the study area and has provided a reference frame for assisting in the development of sustainable land management and ecological protection policy making and decisions.
\end{abstract}

Keywords: Analytical, Binary, Regression, Factors, Sensitivity

\subsection{Introduction}

Sensitivity investigation of external driving factors (EDFs) is a pointer that estimates the variation in the model output with respect to change in the model's input parameters. It is also used for estimating the strength of the model. Burg (2016) asserts that feeding a large amount of data into the model does not always result in better outputs. In fact, the more the data fed into the model, the higher the chances of introducing uncertainty and hence the more error. In this research, sensitivity analysis was performed because the drivers are products of varying processes and prepared at different resolutions. Many of these terms exists, most commonly used are: anthropogenic driving factors in Yichen et al. (2014), influencing factors by Maher et al. (2016) \& (2017). Marcelo et al. (2008) referred to it as proximate causes/ underlying driving factors and Kim et al. (2014) maintained as driving factors; Jiujun (2017) as human factors while in Sanchayeeta et al. (2017) sees it as proximate/ indirect causes of LULCC. Land use land cover changes (LULCC) are significant changes driven by human activities (Alemayehu, 2019). In the history of man, the land has been tightly attached to economic, social, infrastructure and other human activities (Lambin et al., 2003). These changes affects life support functions and humans livelihood (Lambin et al, 2001; Lambin and Geist, 2006). Significant LULCC is caused by a combination of varying factors depending on each locality condition (Hassen et al., 2015; Eyayu et al., 2009; Woldeamlak and Sterk, 2005; Eleni et al., 2013; Mohammed, 2011; Woldeamlak, 2002; Hazem, 2020). 
As observed in the literatures above, different terms are used but they all refer to the same thing. Even though, each term may be given different interpretation under different scenario. This has set in some lack of clarity when dealing with some of these driving factors of LULCC. Therefore, this research adopted the term 'External Driving Factor (EDF)' for consistency and clarity. Various EDFs as used by different studies and understanding the underlying factor (driving mechanisms) of LULCC caused by a variety of driving forces is one of the optimal goals of global change research in recent decades (Xiangmei et al., 2016). To understand the human and biophysical processes of LULCC, many researchers focus on the various forces driving LULCC, including socioeconomic by Xie et al. (2005), demographic in Shi et al. (2010), political by Kanianska et al. (2014), technological as in Hasselmann et al. (2010), biophysical by Serra et al. (2008) and industrial structure in Shu et al. (2014) to provide effective support for developing urban land planning and management regulations. To comprehensively analyse the driving factor's effects and mitigate the negative impacts of LULCC, Shu et al. (2014) investigated the effects of various factors, including natural Eco environment factors, land control policies, accessibility factors, and neighbourhood factors on urban land expansion during various periods in different regions. Chen et al. (2014) selected industrial structure, Gross Domestic Product (GDP), transportation, and policy as the driving factors to study the impacts on urban land expansion and sustainable urban development. Bandit (2018) analysed the spatial relation between independent and dependent variables using Multi binary logistic regression technique. The study concluded that, both biophysical and socio-economic variables had meaningfully contributed to LULC conversions.

Attempts have been on analysing these contributing drivers to LULC dynamics in several parts of the world, notable are Pena et al. (2007); Ellis (2010); Alemayehu et al. (2019) who carried out a comprehensive studies of landscape change to understand the underlying processes and a full range of approaches from the natural and social sciences. Logistic regression model was used to establish the association between socio-economic drivers and LCC in (Dimobe et al., 2015). Similarly, Yuliana and Kaswanto (2016) applied the linear regression equation using the stepwise regression to analyzed drivers of LULCC. Sanchayeete et al. (2017) identified influencing factors of deforestation and simultaneous plantation driven reforestation in Bannerghatta National Park using binary logistic regression likewise the same technique was applied in Mondal et al. (2014) to investigate and analyzed the drivers of LULCC. Due to the fact that a correlation may exist among the selected variables, principal component analysis (PCA) and general linear model (GLM) were employed to identify the relative significance of the driving factors (Xindong et al., 2014). Geospatial analysis method was used to identify drivers of LULCC in (Janina et al., 2017). Yichen et al. (2014) carried out a qualitative analysis of the impacts of drivers on LULC change using Pearson's correlation coefficient where correlation among the built-up areas and the socioeconomic statistics was analyzed. Briassoulis $(2000,2008)$ emphasized the reason why the linkage between LU and LC change in environmental impacts and their contribution to global change are mediated to a considerable extent. Thus, their analysis needs the examination of the ways in which LU relates to LC change at various levels of spatial and temporal detail. LULCC is usually categorized into two broad classes: conversion (a change from LULC category to another e.g. from forest to grassland) and modification (a change within one LULC category e.g. from rain fed cultivated area to irrigated cultivated area) (European Commission, 2001). LC conversion is the complete replacement of one cover type by another such as deforestation to create cropland or pasture (Rachmad, 2014) and these are responsible by some underlying factors. Hassen and Muhamed (2017) identified some major causes of LULCC in Tana watershed.

Uncontrolled landscape expansion is a fundamental problem experienced in many societies of the world today as a result of population explosion. This has been the leading causes of LULCC today in so many parts of the world. Jos metropolis is expanding in all directions (Adzandeh et al., 2015) creating serious environmental problems. Therefore, this research seeks to analyse these LULCC driving factors (external driving factors) to measure how sensitive they are in contributing to the present landscape change in the study area. 


\subsection{Methodology}

\subsection{Study area}

Jos-Bukuru metropolis the study area lies within Jos North and Jos South LGAs of Plateau state. Plateau state as a whole derives her name from Jos plateau (geographical landscape) that dominates this part of country and is located relatively at the Centre of the country Nigeria. Jos lies between longitude $8^{\circ} 40^{\prime} 47.15^{\prime \prime} \mathrm{E}$ and $9^{\circ} 8^{\prime} 13.20^{\prime \prime} \mathrm{E}$, latitude $9^{\circ} 36^{\prime} 11.54{ }^{\prime \prime} \mathrm{N}$ and $10^{\circ} 2^{\prime} 20.51^{\prime \prime} \mathrm{N}$ (Figure 1) covering an area of about 7,780 sqkm with a population close to 900,000 and a population density of 391 persons per $\mathrm{km}^{2}$ making it to be the most densely populated part of plateau state.

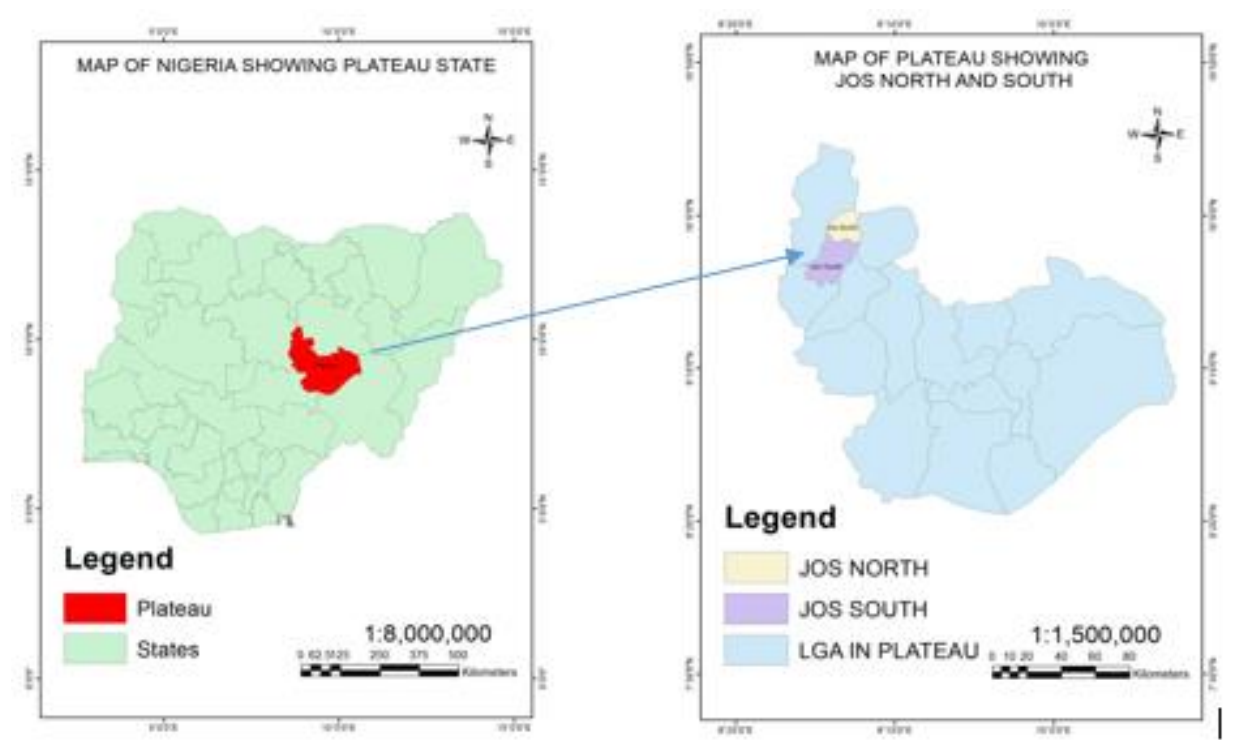

Figure 1: Map of study area

\subsection{Materials}

Table 1 shows the materials used for this research.

Table 1: Materials used

\begin{tabular}{|c|c|c|c|c|}
\hline Data & Instrument/sensor & $\begin{array}{l}\text { Date of } \\
\text { Acquisition }\end{array}$ & Path/row & Source \\
\hline Satellite image & $\begin{array}{l}\text { Landsat } 5 \text { TM } \\
\text { Landsat L7 ETM + } \\
\text { SLC-on } \\
\text { Landsat } 8 \text { OLI } \\
\text { Shuttle Radar } \\
\text { Topographic Mission } \\
\text { (SRTM)1 Arc second } \\
\text { Global } \\
\text { UAV }\end{array}$ & $\begin{array}{l}17 / 1 / 1986 \\
16 / 1 / 2000 \\
15 / 2 / 2019 \\
2015\end{array}$ & $\begin{array}{l}188 / 053 \\
،, \\
\text { ،, } \\
188 / 053\end{array}$ & $\begin{array}{l}\text { http://landsat.usgs.gov/ } \\
\text { ", } \\
\text { https://lta.cr.usgs.gov/SRTM1Arc Global } \\
\text { ML/S and TP Jos }\end{array}$ \\
\hline $\mathrm{X}, \mathrm{Y}$ coordinates & $\begin{array}{l}\text { Garmin Hand held } \\
\text { GPS }\end{array}$ & 2018 & Lat/Long & Field work \\
\hline $\begin{array}{l}\text { Administrative } \\
\text { map } \\
\text { Educational sites } \\
\text { Health sites } \\
\text { Water facilities } \\
\text { Conflict areas } \\
\text { Settlements }\end{array}$ & 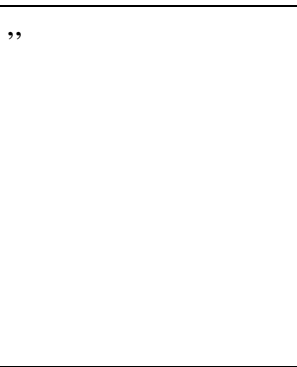 & $\begin{array}{l}2015 \\
\\
2016 \\
2013 \\
2018 \\
2017 \\
2017\end{array}$ & ", & $\begin{array}{l}\text { Ministry of Land Survey/Town Planning } \\
\text { Jos } \\
\text { Humanitarian OpenStreetMap Team } \\
\text { (HOT) } \\
\text { Nigeria MDG information system } \\
\text { " Armed Conflict Location and Event Data } \\
\text { Project Plateau state } \\
\text { National Geospatial-Intelligence Agency } \\
\text { (NGA) Contributor: OCHA Nigeria }\end{array}$ \\
\hline $\begin{array}{l}\text { Slope } \\
\text { Elevation } \\
\text { Digital Elevation } \\
\text { Model (DEM) } \\
\text { Soil }\end{array}$ & $\begin{array}{l}\text { SRTM } \\
, "\end{array}$ & 2010 & $\begin{array}{l}\text { Lat/Long } \\
\text { " } \\
\text { "Lat/Long }\end{array}$ & National centre for Remote Sensing Jos \\
\hline
\end{tabular}




\subsection{Methods}

2.3.1. Determination of external driving factors (EDFS) of LULCC

Deriving external factors to be used for further analysis began by first identifying suspected factors as put forward by some authors Al-sharif and Pradhan (2014); Shafizadeh-Moghadam and Helbich (2015); Arsanjani et al. (2013); Chowdhury and Maithani (2014); Zeng et al. (2015) and Maher et al. (2017). Some of the factors put forward by these authors were adopted and combined with local factors peculiar to the study area as distance to conflict areas and distance to mining areas. In this research, a total of sixteen (16) suspected EDFs (variables) having spatial characteristics were identified and grouped into two as follows: (i) geophysical and (ii) proximity as shown in Table 1. Spatial thresholds were adopted for these layers created as shown in Table 2. They were then weighted and ranked using Saaty's pairwise comparison matrix (see Table 3). Euclidean distance process and reclassification of images was carried out and suitability images finally derived using Equation 1 based on AHP and Binary methods. The EDFs were finally used as independent variables in a multiple regression analysis as shown in Equations 2 and 3 for change otherwise known as sensitivity analysis. This process allows the analyst to identify the less important factors, thereby making use of the most relevant factors.

Table 2: Lists of Suspected External Driving Factors (EDFs)

\begin{tabular}{|c|c|c|}
\hline Category & Driving factors & Description \\
\hline Geophysical & $\begin{array}{l}\text { Slope } \\
\text { Elevation } \\
\text { Soil } \\
\end{array}$ & SRTM 1 arcsecond 30m GSD \\
\hline $\begin{array}{l}\text { Neighbourhood effect as } \\
\text { Proximity to environmentally } \\
\text { sensitive/prominent areas }\end{array}$ & $\begin{array}{l}\text { Land use Land cover } \\
\text { Distance to market/ Commercial area } \\
\text { Distance to industrial area } \\
\text { Distance to water body } \\
\text { Distance to mines area } \\
\text { Distance to river } \\
\text { Channels } \\
\text { Distance to settlements } \\
\text { Distance to conflict areas }\end{array}$ & $\begin{array}{l}\text { Pixel } \\
\text { Euclidean distance to nearest } \\
(\mathrm{Km})\end{array}$ \\
\hline Proximity to Utilities & $\begin{array}{l}\text { Distance to Major roads } \\
\text { Distance to railway } \\
\text { Distance to water facility } \\
\text { Distance to Health care } \\
\text { Distance to Educational area }\end{array}$ & $\begin{array}{l}\text { Pixel } \\
\text { Euclidean distance to nearest } \\
(\mathrm{Km})\end{array}$ \\
\hline
\end{tabular}

Table 3: Adopted thresholds for suspected EDFs

\begin{tabular}{|lll|}
\hline S/No & Factors & Distance \\
\hline 1 & Major road & $15.00 \mathrm{~m}$ \\
2 & Water facilities & $200.00 \mathrm{~m}$ \\
3 & Health care & $500.00 \mathrm{~m}$ \\
4 & Education & $500.00 \mathrm{~m}$ \\
5 & Market/commercial & $400.00 \mathrm{~m}$ \\
6 & Industrial & $500.00 \mathrm{~m}$ \\
\hline 7 & Water body & $100.00 \mathrm{~m}$ \\
8 & Mining area & $100.00 \mathrm{~m}$ \\
9 & Railway & $50.00 \mathrm{~m}$ \\
\hline 10 & Slope & $<15^{\circ}$ \\
11 & River & $30.00 \mathrm{~m}$ \\
12 & Conflict area & $1000.00 \mathrm{~m}$ \\
13 & Settlements & $1000.00 \mathrm{~m}$ \\
\hline
\end{tabular}

\subsubsection{Generate suitability images}

Euclidean distance images were first generated for all the EDFs followed by reclassification process based on the thresholds adopted in this work as shown in Table 3. The reclassified images based on AHP and Binary methods were multiplied through raster calculator in ArcGIS 10.1 by the corresponding weights computed as shown in Table 4. Therefore a total of thirty two (32) images were generated with sixteen each from AHP and Binary methods. Equation 1 shows how each of the suitability index maps was created.

$S_{i, j}^{t}=X_{i, j}^{t} \cdot W_{m} \cdot C_{m}$ 
Where:

$S_{i, j}^{t}=$ Suitability indexes for cell ij at time $t$

$X_{i, j}^{t}=$ Criteria $m$ at cell $i j$ at time $t$

$C_{m}=$ Constraint value

$W_{m}=$ Weight for criteria $m$

Suitability index map $S_{i, j}^{t}$ base on EDFs generated through AHP model is given as $U_{i, j \_A H P}^{t}$ while EDFs generated using Binary model is given as $V_{i, j_{B} B M}^{t}$. It is important to state that all the factors do not influence the rate of urban growth in the same way due to polarity. For instance, a high population density of a region will create more pressure for the conversion of natural resources. Contrary to this, the rate of urban growth will be high in those areas near the city centre. Therefore, a fuzzy set standardization procedure was followed to remove the conflicting character in the dataset and to make all factors unidirectional with an equal scale. Images were standardized to a common scale of 0-255 that is all the factors were brought to a common measurement unit or scale (suitability). A value of 255 indicates the highest suitability and a value 0 indicates the lowest suitability of that particular category.

\subsubsection{Multiple regression analysis (MRA)}

The general multiple regression (MR) formula as shown in Equation 2 was performed to analyze the relationship of one or more independent variables on a single dependent variable. The regression was conducted for image files of the various EDFs (independent variables) and the LULCC of $t_{1}-t_{3}$ as the dependent variable. This was performed in Idrisi selva 17.0 software through GIS analysis/statistics/multireg module for both AHP and Binary suitability images. The Multiple regression equation for AHP and Binary suitability images takes the form as is given in Equation 3 and 4 respectively.

$$
\begin{aligned}
& Y=A+B x_{1}+C x_{2}+D x_{3} \\
& Y=a+b_{1} U_{i, j_{\_} A H P_{1}}+b_{2} U_{i, j_{-} A H P_{2}}^{t}+\cdots+b_{n} U_{i, j_{-} A H P_{n}}^{t} \\
& Y=a+b_{1} V_{i, j_{\_} B M_{1}}^{t}+b_{2} V_{i, j_{-} B M_{2}}+\cdots+b_{n} V_{i, j_{\_} B M_{n}}^{t}
\end{aligned}
$$

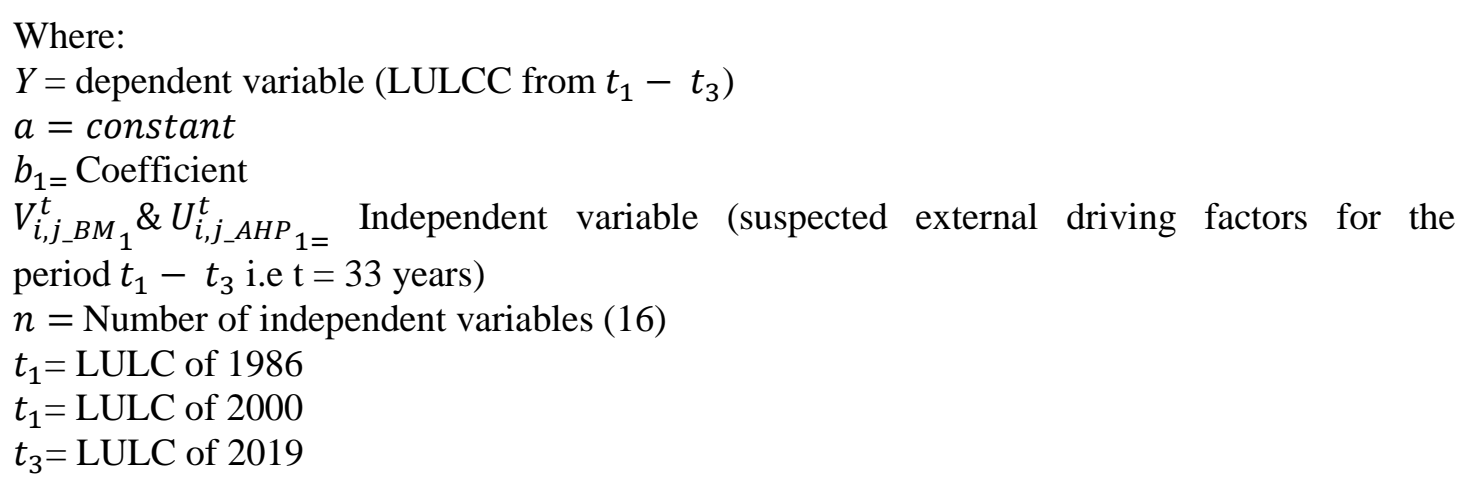

\subsubsection{Final selection of appropriate external driving factors (EDFs)}

This was achieved through the result of MR by considering the corresponding sign either positive or negative as displayed by regression coefficients ( $r$ ) which is also known as slope coefficient. Independent variables with consistent behavior from both models were selected as the final appropriate EDFs. A positive sign means as the dependent variable increases, the independent variable also increases and both variables move in the same direction while a negative sign indicates an increase in the dependent brings about a decrease in the independent variable and both variables move in opposite direction (Jim, 2019) .

\subsection{Results and Discussion}

The results showing weights of all the EDFs are displayed in Table 4 after formulation of pairwise comparison matrix. A consistency ratio (CR) of 0.017 was achieved which is slightly above the 0.1 target, and the weight sum up to 1.0000. It can also be deduced that, factors like Elevation, distance to market and distance to river are having higher weights while slope, soil, distance to mining area and 
distance to water body are having the lowest weights. This may be attributed to one of the major drawbacks of method adopted (Saaty's pairwise) that is, varying expert's opinion. Table 5 is the result of MR performed on the thirty two (32) EDFs with sixteen (16) each from both methods after performing fuzzy set standardization. The analysis of this result shows that LULC, distance to conflict areas, distance to river/channels and distance to settlements are proximity to environmentally sensitive/prominent areas while distance to major roads is proximity to utilities.

Table 4: Computed weights based on Saaty's pairwise comparison matrix

\begin{tabular}{|l|l|}
\hline EDF & Weight \\
\hline Slope & 0.022914 \\
\hline Elevation & 0.120186 \\
\hline Soil & 0.028115 \\
\hline Distance to market & 0.129463 \\
\hline Distance to mining area & 0.027708 \\
\hline Distance to river & 0.111799 \\
\hline Distance to water body & 0.027267 \\
\hline Distance to industrial area & 0.081956 \\
\hline Distance to major roads & 0.032135 \\
\hline Distance to conflict areas & 0.071796 \\
\hline Distance to settlements & 0.035343 \\
\hline LULC & 0.075569 \\
\hline Distance to water facilities & 0.051091 \\
\hline Distance to railway & 0.075197 \\
\hline Distance to health care & 0.056344 \\
\hline Distance to educational areas & 0.053119 \\
\hline
\end{tabular}

$\mathrm{CI}=0.27164$

$\mathrm{RI}=1.5978$

$\mathrm{n}=16$

$\lambda_{\max }=20.07459$

$\mathrm{CR}=0.17000$

Table 5: Selected appropriate EDFs

\begin{tabular}{|l|l|l|l|}
\hline S/N & EDFs & r coefficient (Binary) & $\mathrm{r}$ coefficient (AHP) \\
\hline 1 & Distance to conflict areas & 0.001417 & 0.183332 \\
\hline 2 & LULC & 0.016682 & 2.702839 \\
\hline 3 & Distance to major roads & 0.001730 & 0.040826 \\
\hline 4 & Distance to settlements & 0.005624 & 0.051394 \\
\hline 5 & Distance to river| channels & 0.003778 & 0.000784 \\
\hline
\end{tabular}

Result in Table 5 above shows the EDFs that were consistent in their influence or behaviour against the change period of study. In this study, emphasis was on the sign (direction of the relationship) not the magnitude of coefficient as the case has always been. Direction of relationship is very important in this research because, much attention is drawn to spatial movements. As landscape changes to which direction, what are the influencing EDFs that are responsible for those changes in that direction? The images as shown in Figures $2 \mathrm{a}-2 \mathrm{e}$ are the results derived from AHP method, while Figures $2 \mathrm{f}-2 \mathrm{j}$ are from Binary method. These are the final selected EDFs contributing to the changing landscape of the study area. These images shows areas that are suitable and not suitable for urban land development in the study area as presented using two different methods. The AHP image displays a suitability range from $0-255$, that is suitability of any portion in the study area is dependent on the pixel value. Similarly, for binary images, they are 1 and 0 . Areas with pixel value 1 are suitable while areas with 0 are not suitable for urban land development. 


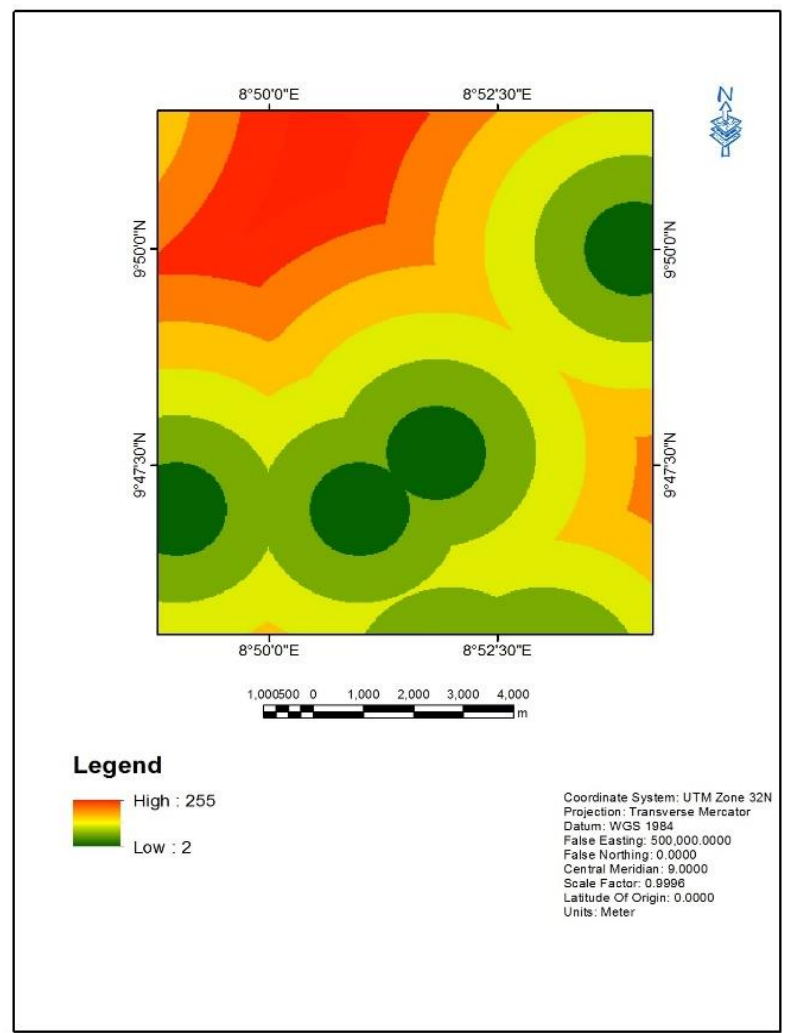

Figure 2a: Distance to conflict areas

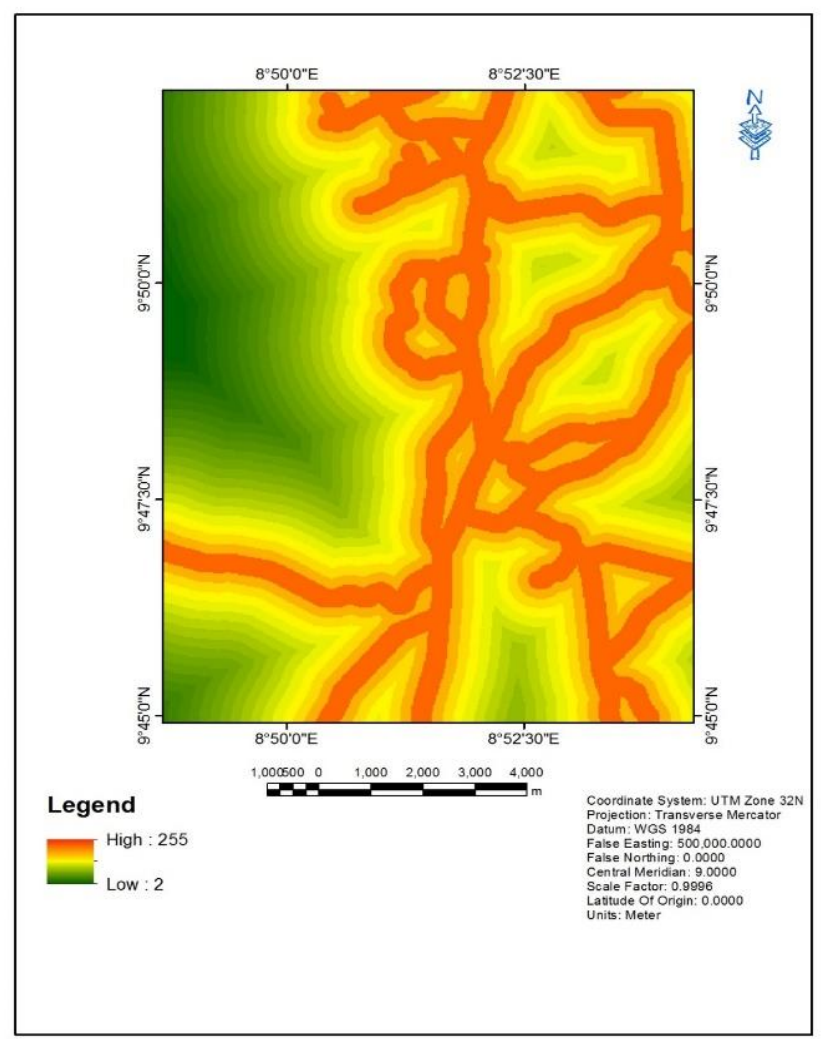

Figure 2c: Distance to major roads

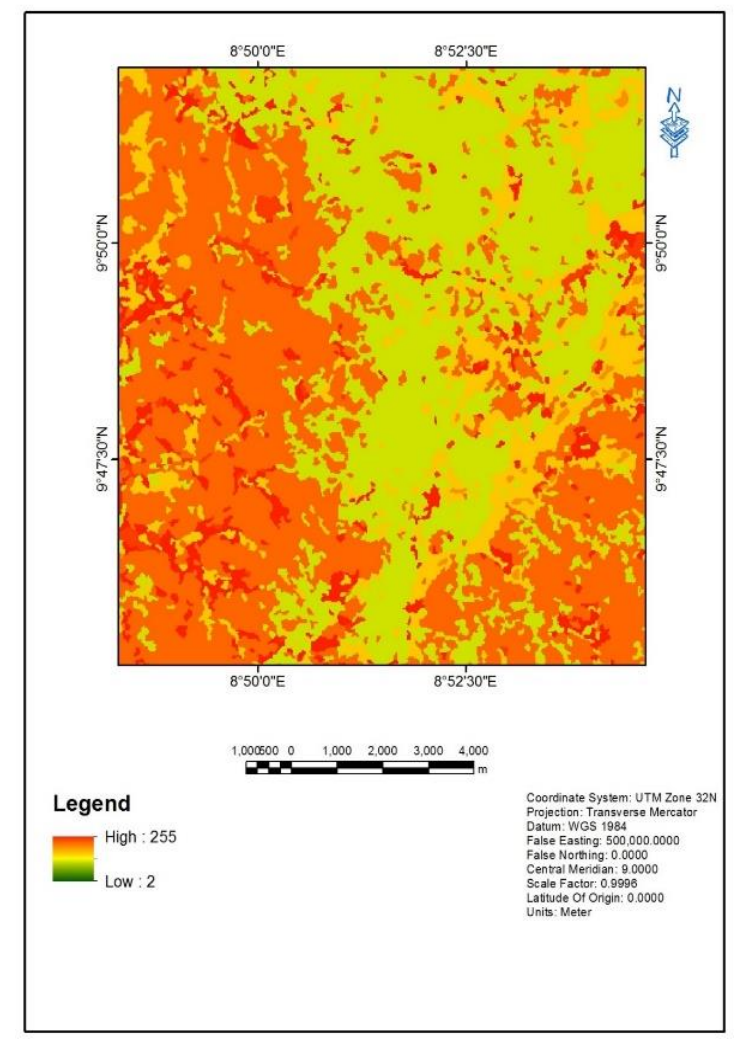

Figure 2b: LULC

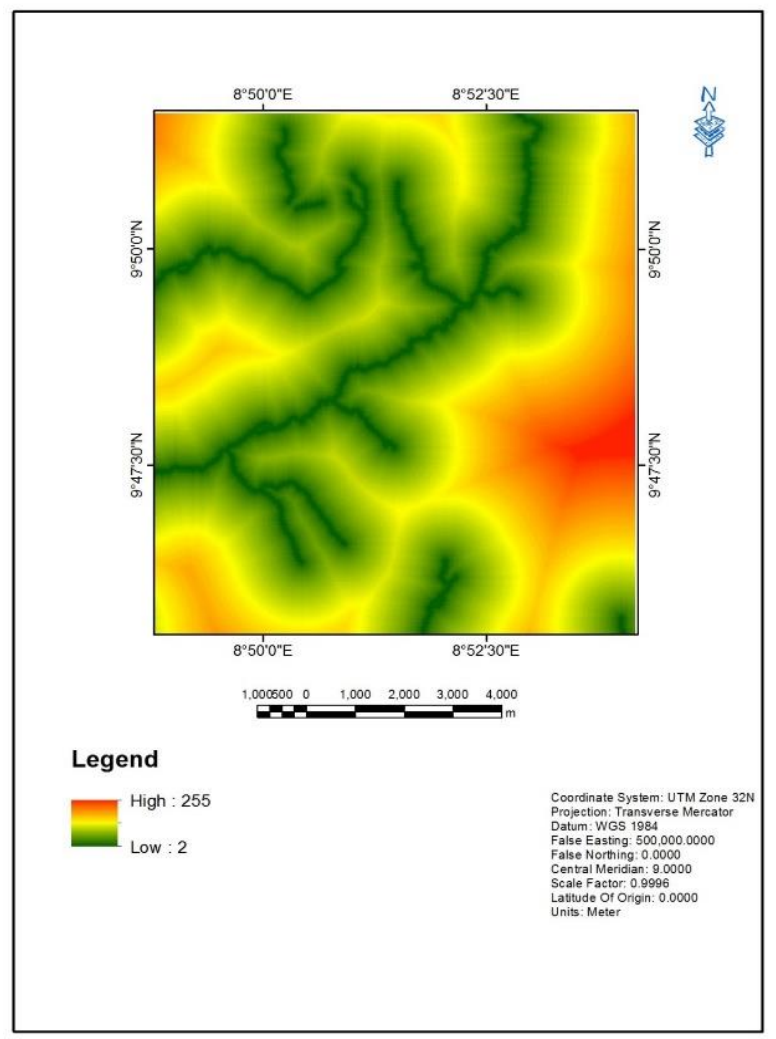

Figure 2d: Distance to river channel 


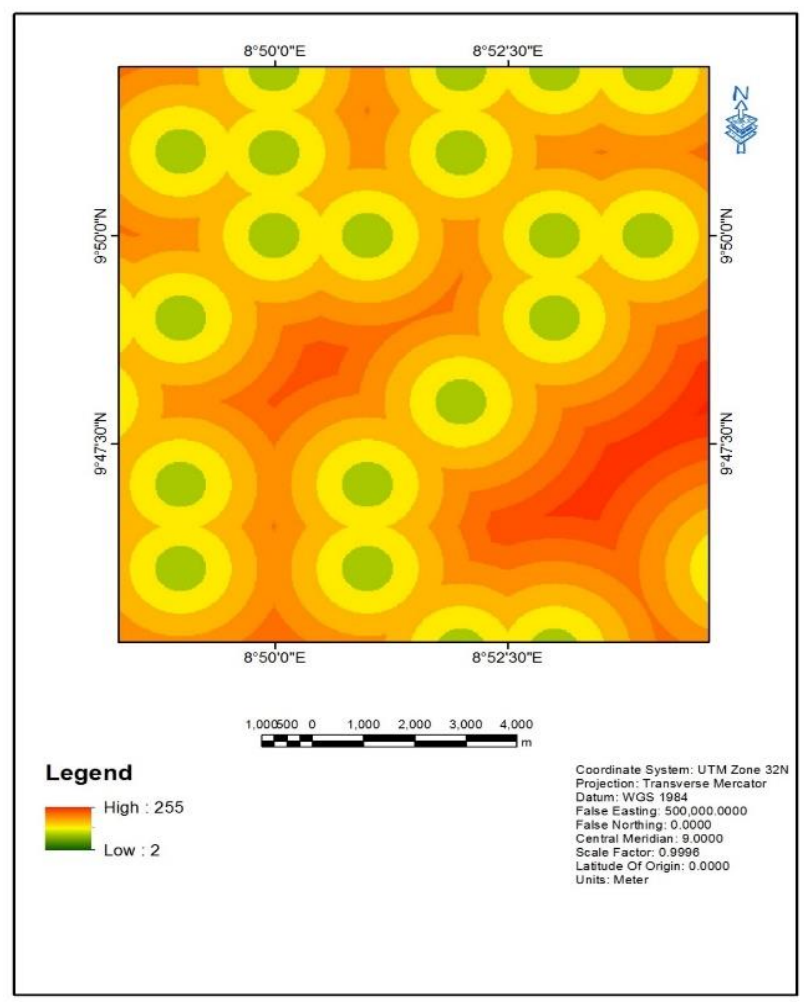

Figure 2e: Distance to settlements

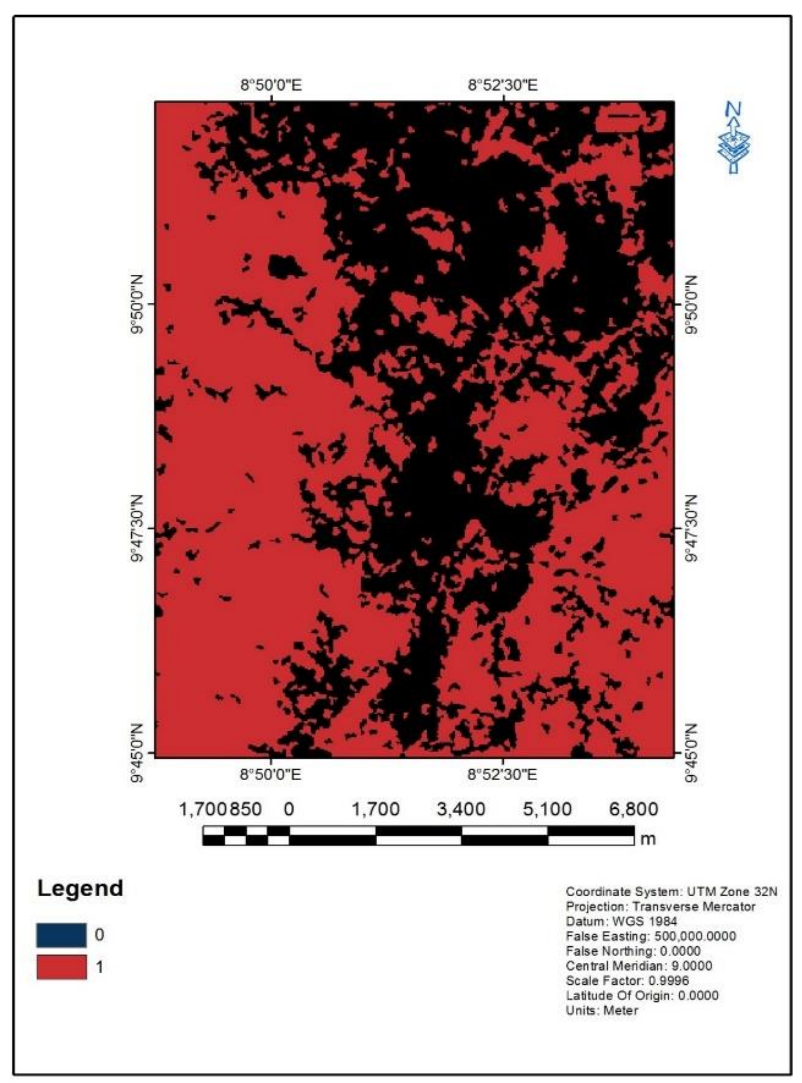

Figure 2g: LULC

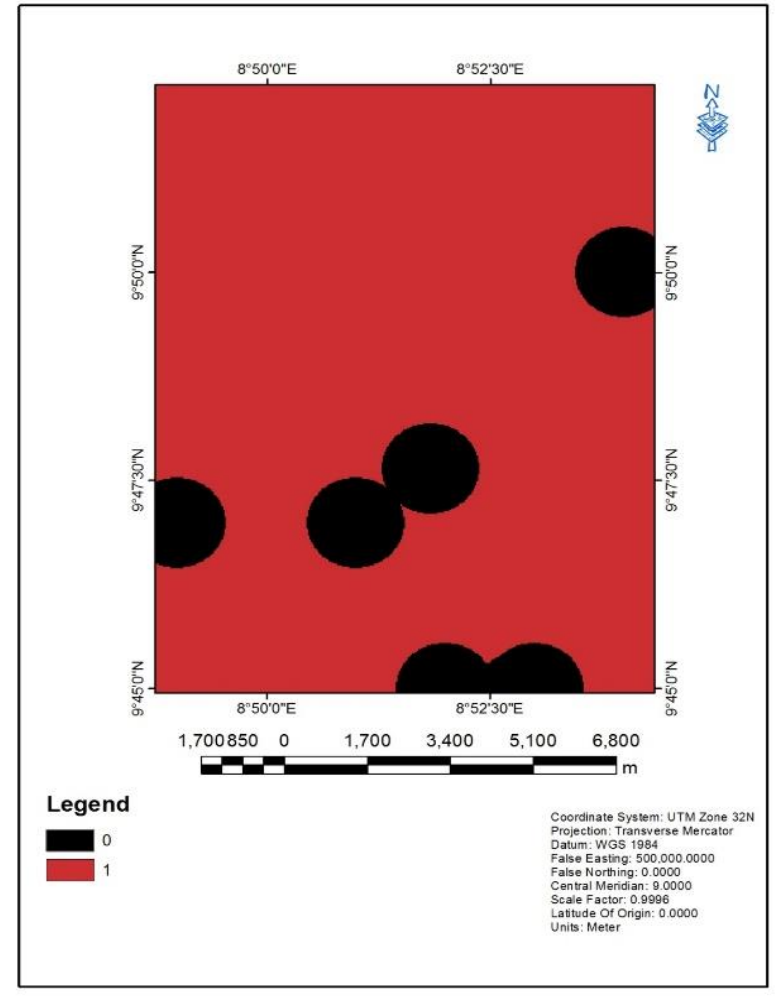

Figure 2f: Distance to conflict areas

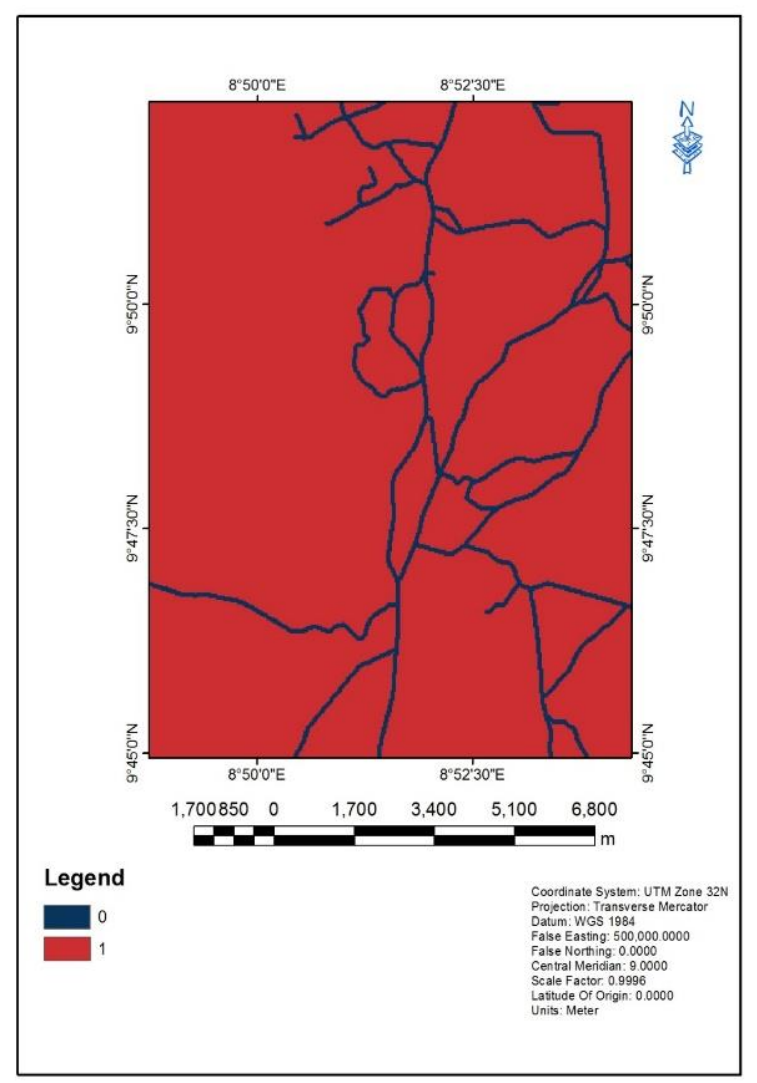

Figure 2h: Distance to major roads 


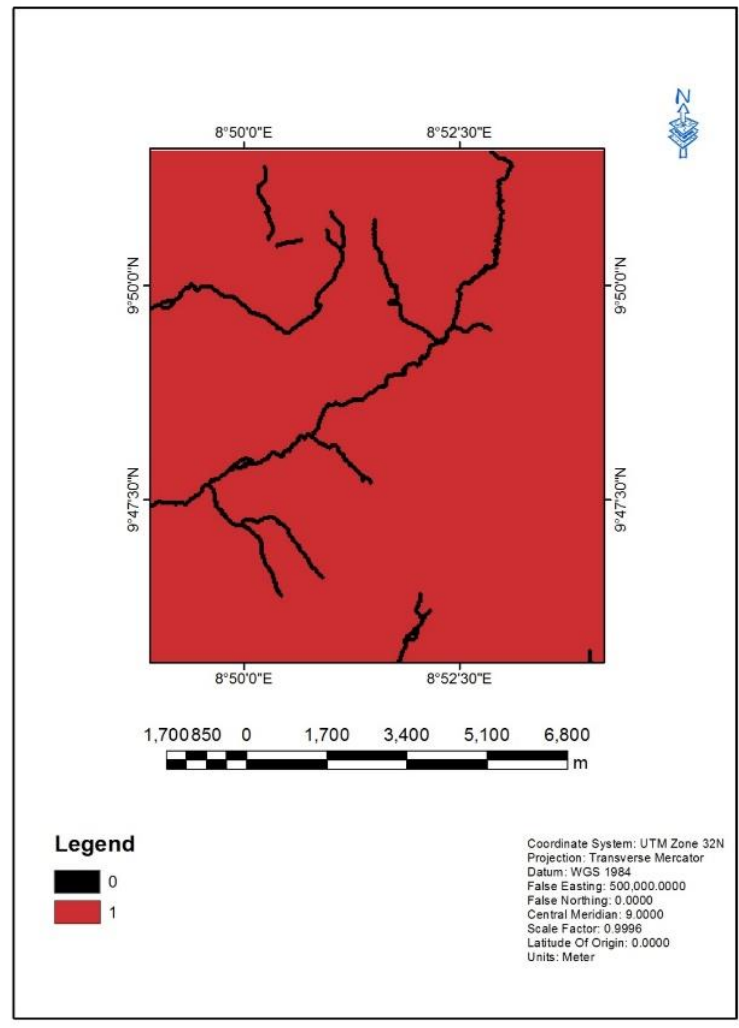

Figure 2i: Distance to river channels

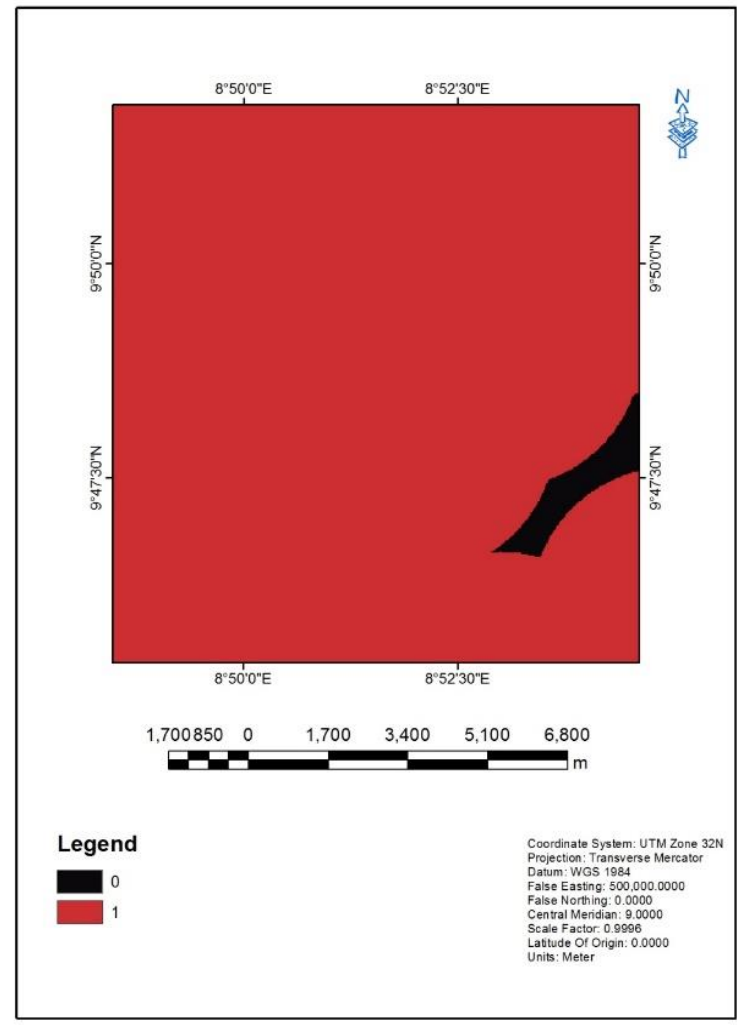

Figure 2j: Distance to settlements

Distance to major roads: the influence on landscape change is predominantly in the north running through the central towards the east and down to the southern part of the research area as seen in Figure 2a \& 2h. In Adzandeh et al. (2015), the rate of land development in Jos is alarming. This is further confirmed in this research as a result of massive roads construction, other sub-urban settlements like Kwang, Lamingo Haske, Gwafang, Ten Commandments, Guratop and Du have witnessed increased urban land development. These newly constructed roads have greatly influenced the cost of landed properties and standard of living in these areas. They are now major alternative routes (bye-pass) for transporters easing traffic gridlock usually experienced in the city centre. Land use Land cover (LULC): as seen in Figures $2 \mathrm{~b} \& 2 \mathrm{~g}$ respectively, there is little or no effect of potential land development in the northern part through the central down to the south of the study area. This is due to the existing developments, but the LULC is a pointer to other parts like the west and some part of south east as highly suitable for developments.

Distance to river channels: apart from the main river channels as shown in Figures $2 \mathrm{~d} \& 2 \mathrm{i}$, other areas around the EDF clearly indicates the suitability of land development in all directions of the study area. This is quite typical of the settlement expansion witnessed today in Jos as most residents along this EDF takes advantage of proximity and engage in both dry and rainy season farming. Distance to conflict areas is also another influencing factor of land development as shown in Figures $2 \mathrm{a} \& 2 \mathrm{f}$ respectively. The dark spots on the images are vulnerable areas and can be seen around the south, some part of east and south west areas. Suitability of land development in the study area is towards the central to the northern area and some parts south east. Also, Adzandeh (2015) pointed out that these areas are constantly witnessing a decline in urban land development since 1984. Distance to settlements: the spatial distribution of existing settlement has equally influenced the development or existence of other settlements due to proximity. Figures $2 \mathrm{e} \& 2 \mathrm{j}$ shows that almost all parts of the study area are suitable for urban land development as a result of the already existing settlements. Even though, in the Binary suitability image it shows that only a small portion in the south east is not suitable. This implies that, it is safer to live close to each other than stay in isolation because of prevailing factors like conflicts and insecurity.

\subsection{Conclusions}

To determine the drivers of change, sixteen (16) suspected external driving factors (EDFs) were identified as those of geophysical, neighbourhood effect as proximity to environmentally sensitive 
areas and proximity to utilities. Euclidean distance analysis was carried out on the proximity EDFs and reclassification based on AHP scale $1-9$ and binary mode as $1 \& 0$. The Saaty's pairwise comparison matrix was generated and weights for all the EDFs were computed with a consistency index (CI) of 0.17. Suitability images were generated by multiplying each EDF with the corresponding weight. The fuzzy set membership standardization was carried out on the AHP image through sigmoidal function type with monotonically increasing membership function. The Multiple regression technique was used to measure the sensitivity of all the EDFs (images) against the change image (1986 - 2019). Based on the regression analysis, five (5) EDFs were consistent in both approaches (AHP and Binary). They are: LULC, distance to conflict areas, distance to river/channels and distance to settlements are proximity to environmentally sensitive/prominent areas while distance to major roads is proximity to utilities.

\section{Declaration of interest}

The authors declare no conflict of interest.

\section{References}

Adzandeh, E. A., Akintunde, J. A. and Akintunde, E. A. (2015). Analysis of Urban Growth Agents in Jos Metropolis, Nigeria. International Journal of Remote Sensing and GIS, 4(2), pp. 41-50.

Alemayehu, F., Motuma, T. and Gizaw, T. (2019). Land Use Land Cover Change Trend and Its Drivers in Somodo Watershed South Western, Ethiopia. African Journal of Agricultural Research 14(2), pp. 102-117. DOI: 10.5897/AJAR2018.13672

Al-sharif, A. A. and Pradhan, B. (2014). Monitoring and predicting land use change in Tripoli Metropolitan City using an integrated Markov chain and cellular automata models in GIS. Arab $J$ Geosci, 7(10), pp. 4291-4301.

Arsanjani, J. J., Helbich, M., Kainz, W. and Darvishi, A. (2013). Integration of logistic regression, markov chain and cellular automata models to simulate urban expansion - the case of Tehran. International journal of applied earth observation and Geo-information, 21, pp. 265 - 275.

Bandit, M. (2018). Analysis of land use and land cover changes and the driving forces: A case study in Kaysone Phomvihan District, Laos Dissertation of Master in Geographic Information Systems and Spatial Planning Faculty of Arts, University of Porto.

Briassoulis, H. (2000). Analysis of land use change: theoretical and modeling approaches. Regional Research Institute.

Briassoulis, H. (2008). Land-use policy and planning, theorizing, and modeling: lost in translation, found in complexity? Environment and Planning B: Planning and Design, 35(1), pp. 16-33. doi:10.1068/b32166.

Burg, M. B. (2016). Uncertainty and Sensitivity Analysis in Archaeological Computational Modeling. https://doi.org/10.1007/978-3-319-27833-9

Chen, J., Chang, K.-T., Karacsonyi, D. and Zhang, X. (2014). Comparing urban land expansion and its driving factors in Shenzhen and Dongguan, China. Habitat International, 43, pp. 61-71.

Chowdhury, P. R. and Maithani, S. (2014). Modelling urban growth in the Indo-Gangetic plain using night-time OLS data and cellular automata. Int. J. Appl. Earth Obs. Geoinf. 33, pp. 155-165.

Dimobe, K., Amadé, O., Soungalo, S., Dethardt, G., Stefan, P. and Adjima, T. (2015). Identification of driving factors of land degradation and deforestation in the Wildlife Reserve of Bontioli (Burkina Faso, West Africa). Global Ecology and Conservation, 4, pp. 559-571. 
Eleni, Y., Wolfgang, W., Michael, E., Dagnachew, L. and Günter, B. (2013) Identifying land use/cover dynamics in the koga catchment, Ethiopia, from multi-scale data, and implications for environmental change. ISPRS Int J Geo Inf, 2, pp. 302-323.

Ellis, E. (2010). Land-use and land-cover change. The Encyclopedia of Earth. Retrieved September 10, 2019, from http://www.eoearth.org/view/article/ 154143/

European Commission. (2001). Manual of concepts on land cover and land use information systems (p. 106). Luxembourg.

Eyayu, M., Heluf ,G., Tekalign, M. and Mohammed, A. (2009). Effects of land-use change on selected soil properties in the tara gedam catchment and adjacent agro-ecosystems, North West Ethiopia. Ethiop J Nat Res, 11, pp. 35-62.

Hasselmann, F., Csaplovics, E., Falconer, I., Burgi, M. and Hersperger, M. (2010). Technological driving forces of LUCC: conceptualization, quantification, and the example of urban power distribution networks. Land Use Policy, 27(2), pp. 628-637.

Hassen, E. E. and Mohamed, A. (2017). Land use/cover dynamics and its drivers in Gelda catchment, Lake Tana watershed, Ethiopia. Environ Syst Res, 6(4). DOI 10.1186/s40068-017-0081-x

Hassen, M. Y., Mohammed, A., Assefa, M. and Tena, A. (2015). Detecting land use/land cover changes in the Lake Hayq (Ethiopia) drainage basin, 1957-2007. Lakes Reserv, 20, pp. 1-18.

Hazem, T. A. E. (2020). Geospatial Analyses for Assessing the Driving Forces of Land Use/Land Cover Dynamics around the Nile Delta Branches, Egypt. Journal of the Indian Society of Remote Sensing, 48(12), pp. 1661-1674. https://doi.org/10.1007/s12524-020-01189-2

Janina, K., Gülendam, B., Henry, N. N. B. and Christine, F. (2017). Assessing driving forces of land use and land cover change by a mixed-method approach in north-eastern Ghana, West Africa. Journal of Environmental Management, 196(2017), pp. 411-442.

Jim, F. (2019). Regression coefficient. https://statistics by Jim.com/glossary/regression-coefficient. Accessed 10/09/2021

Jiujun, L. (2017). Using Historical Remote Sensing Image to Predict Future Land Use in Panjin City, China. AIP Conference Proceedings 1864, 020175; doi: 10.1063/1.4992992. Published by the American Institute of Physics

Kanianska, R., Kizekova, M., Nov'a'cek, J. and Zeman, M. (2014). Land- use and land-cover changes in rural areas during different political systems: a case study of Slovakia from 1782 to 2006. Land Use Policy, 36, pp. 554-566.

Kim, I., Quang, B. L., Soo Jin, P., John, T. and Thomas, K. (2014). Driving Forces in Archetypical Land-Use Changes in a Mountainous Watershed in East Asia. Land, 3, pp. 957-980. doi:10.3390/land3030957

Lambin, E. F. and Geist, H. J. (2003). Global land-use and land-cover change: what have we learned so far? Global Change News Letter, 46, pp. 27-30.

Lambin, E. F. and Geist, H. J. (2006). Land use and land cover change: local processes and global impacts. Springer, Berlin

Lambin, E. F. et al (2001). The causes of land-use and land-cover change: moving beyond the myths. Glob Environ Chang, 11, pp. 261-269.

Maher, M. A., Sabrina, H. A., Mohammad, F. R. and Zulfa, H. A. (2016). Landscape analysis of urban growth patterns in Seremban, Malaysia, using spatio-temporal data. 8th IGRSM International 
Conference and Exhibition on Remote Sensing and GIS (IGRSM 2016) IOP Publishing. IOP Conf. Series: Earth and Environmental Science 37, 012055 doi:10.1088/1755-1315/37/1/012055

Maher, M. A., Yuek, M. H, Mohammad, F. R. and Zulfa, H. A. (2017). Improving the capability of an integrated CA-Markov model to simulate spatio-temporal urban growth trends using an Analytical Hierarchy Process and Frequency Ratio. International Journal of Applied Earth Observation and Geoinformation, 59, pp. 65-78.

Marcelo, R. Z., Marcelo, C., Daniel, C. and Sandra, D. (2008). What Drives Accelerated Land Cover Change in Central Argentina? Synergistic Consequences of Climatic, Socioeconomic, and Technological Factors. Environmental Management, 42, pp. 181-189. DOI 10.1007/s00267-0089101-y

Mohammed, A. (2011). Land use/cover dynamics and its implications in the dried lake Alemaya watershed, eastern Ethiopia. J Sustain Dev Afr. 13(4), pp. 1-18.

Mondal, M. S., Nayan, S., Garg, P. K. and Martin, K. (2016). Statistical independence test and validation of CA_Markov land use land cover (LULC) prediction results. The Egyptian Journal of Remote Sensing and Space Sciences, 19, pp. 259-272.

Pena, J., Bonet, A., Bellot, J., Sanchez, J., Eisenhuth, D., Hallett, S. \& Aledo, A. (2007). Driving forces of land-use change in a cultural landscape of Spain: preliminary assessment of the humanmediated influences. Kommen (Ed.), Modelling Land-Use Change, (pp. 97-115). Springer.

Rachmad, F. (2014). Assessing Land Use and Land Cover Change toward Sustainability in Humid Tropical Watersheds, Indonesia. Doctoral dissertation at Graduate School for International Development and Cooperation Hiroshima University.

Sanchayeeta, A., Timothy, F. and Puneet, D. (2017). Proximate Causes of Land-Use and Land-Cover Change in Bannerghatta National Park: A Spatial Statistical Model. Forests, 8, 342; doi: $10.3390 / f 8090342$

Serra, P., Pons, X. and Saur, D. (2008). Land-cover and land-use change in a Mediterranean landscape: a spatial analysis of driving forces integrating biophysical and human factors. Applied Geography, 28(3), pp. 189-209.

Shafizadeh-Moghadam, H. and Helbich, M. (2015). Spatiotemporal variability of urban growth factors: a global and local perspective on the megacity of Mumbai. Int. J. Appl. Earth Obs. Geoinf. 35, pp. 187-198.

Shi, Y., Wang, R., Fan, L., Li, J. and Yang, D. (2010). Analysis on land use change and its demographic factors in the original-stream watershed of Tarim River based on GIS and statistic. Procedia Environmental Sciences, 2, pp. 175-184.

Shu, B., Zhang, H., Li, Y., Qu, Y. and Chen, L. (2014). Spatiotemporal variation analysis of driving forces of urban land spatial expansion using logistic regression: a case study of port towns in Taicang City, China. Habitat International, 43, pp. 181-190.

Woldeamlak, B. (2002). Land cover dynamics since the 1950s in chemoga watershed, Blue Nile Basin. Mt Res Dev, 22(3), pp. 263-269.

Woldeamlak, B. and Sterk, G. (2005) Dynamics in land cover and its effect on stream flow in the chemoga watershed, Blue Nile basin, Ethiopia. Hydrol Process, 19, pp. 445-458.

Xiangmei, L., Ying, W., Jiangfeng, L and Bin, L (2016). Physical and Socioeconomic Driving Forces of Land-Use and Land-Cover Changes: A Case Study of Wuhan City, China. Hindawi Publishing Corporation Discrete Dynamics in Nature and Society Volume 2016, Article ID 8061069, 11 pages http://dx.doi.org/10.1155/2016/8061069 
Xie, Y., Mei, Y., Guangjin, T. and Xuerong, X. (2005). Socio-economic driving forces of arable land conversion: a case study of Wuxian City, China. Global Environmental Change, 15(3), pp. 238-252.

Xindong, D., Xiaobin, J., Xilian Yang, X. Y and Yinkang, Z (2014). Spatial Pattern of Land Use Change and Its Driving Force in Jiangsu Province. Int. J. Environ. Res. Public Health, 11, pp. 32153232; doi:10.3390/ijerph110303215

Yichen, T., Kai, Y., Dengsheng, L., Lizhong, H., Qianjun, Z and Meiping W. (2014) Examining Land Use and Land Cover Spatiotemporal Change and Driving Forces in Beijing from 1978 to 2010. Remote sensing 6 ISSN 2072-4292 www.mdpi.com/journal/remotesensing

Yuliana, A, and Kaswanto (2016). Analysis of land use and cover changes in Ciliwung and Cisadane Watershed in three decades. The 2nd International Symposium on LAPAN-IPB Satellite for Food Security and Environmental Monitoring 2015, LISAT-FSEM.

Zeng, C., Liu, Y., Stein, A and Jiao, L (2015). Characterization and spatial modelling of urban sprawl in the Wuhan Metropolitan Area, China. Int. J. Appl. Earth Obs. Geoinf. 34, pp. 10-24.

\section{Cite this article as:}

Zitta N., Musa A. A. and Muhammed I., 2022. Sensitivity Analysis of Suspected External Driving Factors Contributing to Land Use Land Cover Dynamics in Jos Plateau State Nigeria. Nigerian Journal of Environmental Sciences and Technology, 6(1), pp. 58-70. https://doi.org/10.36263/nijest.2022.01.0297 